\title{
Modulations of Immune Functions and Oxidative Status Induced by Noise Stress
}

\author{
Kui-Cheng ZHENG $^{1,2}$ and Makoto ArIIZumi ${ }^{1}$
}

${ }^{1}$ Department of Environmental and Preventive Medicine, Faculty of Medicine, University of the Ryukyus, Japan and ${ }^{2}$ Department of Environmental and Occupational Health, Graduate School of Public Health, University of Pittsburgh, USA

\begin{abstract}
Modulations of Immune Functions and Oxidative Status Induced by Noise Stress: KuiCheng Zheng, et al. Department of Environmental and Preventive Medicine, Faculty of Medicine, University of the Ryukyus-Noise has long been realized as an environmental stress causing physiological, psychological and behavioral changes in humans. The aim of the present study was to determine the effect of acute or chronic noise stress on both cellular and humoral immune responses and oxidative status. BALB/c mice were exposed to $90 \mathrm{~dB}$ (A) white noise $5 \mathrm{~h}$ per day for either $3 \mathrm{~d}$ or $4 \mathrm{wk}$. Hormone levels, splenic lymphocyte proliferation, lymphocyte subsets in spleen and thymus, serum antibody and oxidative status were determined. A 3-d exposure to noise stress resulted in increased hormone levels, splenic lymphoproliferation and serum IgM. On the other hand, a 4-wk exposure to noise stress caused a reduction of splenic lymphoproliferation, splenic CD4+ cells and serum IgG, but hormone levels and urinary 8-hydroxy-2'deoxyguanosine (8-OHdG) were increased. These results imply that acute exposure to noise stress may enhance immune responses, whereas chronic exposure to noise stress may suppress both cellular and humoral immune functions. The effect of noise stress on immune functions may be related to neuroendocrine modulation and oxidative imbalance as well.
\end{abstract}

(J Occup Health 2007; 49: 32-38)

Key words: Noise stress, Cellular immune response, Humoral immune response, Neuroendocrine, Oxidative stress

Noise, an environmental stressor, has been known as a

Received Jun 30, 2006; Accepted Oct 13, 2006

Correspondence to: K.-C. Zheng, Department of Environmental and Preventive Medicine, Faculty of Medicine, University of the Ryukyus, 207 Uehara, Nishihara, Okinawa 903-0215, Japan (e-mail: kuizheng@hotmail.com) health risk not only for workers in a variety of occupations, but also for the general population. Along with rapid industrialization in many developing countries, noise exposure is on an increasing trend, both in industrial areas and general living areas. Evidence has shown that noise exposure may produce hearing loss, sleep disturbance and stress-related health effects such as annoyance, hypertension and ischemic heart disease ${ }^{1)}$. A study performed in aircraft workers revealed that exposure to large pressure amplitude and low frequency noise resulted in a high prevalence of oropharynx infections of viral, bacterial and fungal origins ${ }^{2}$. A study carried out on animals indicated that noise exposure prolonged healing of surgical wounds made on rats' backs ${ }^{3)}$. These results imply a potential immunosuppressive effect of noise stress in humans and animals. However, generally the effect of noise stress on the immune system has not been well defined. Only a few animal models, particularly of the mouse and rat, have been used to explore the changes of the immune function after exposure to noise, but the results of these studies are not consistent. Moreover, most of these studies in animals have mainly targeted the cellular immune responses such as the absolute numbers of lymphocytes or leucocytes, lymphocyte activity or natural killer (NK) cell activity, and the evidence for changes of the humoral immune response caused by noise stress is very limited.

It has been known that environmental stress may cause oxidative DNA damage ${ }^{4)}$. Oxidative stress has been reported to be an important factor in the cascade of cochlear events resulting from noise or medication induced sensorineural hearing loss ${ }^{5,6)}$. However, little is known about the interaction of oxidative stress and immune response in the pathogenesis of disorder induced by noise exposure.

The purpose of this study was to further investigate the effect of noise stress on both cellular and humoral immune responses, and on general oxidative damage 
simultaneously. To achieve this, immune functions and oxidative status were determined within the same animal.

\section{Materials and Methods}

\section{Animals}

Six-week-old male BALB/c mice, weighing 20-25 g, were used for the study. To avoid stress caused by isolation or overpopulation, each cage $(30 \times 36 \times 16 \mathrm{~cm})$ contained 2 or 3 mice. The mice were kept in a room under constant temperature $\left(25 \pm 2^{\circ} \mathrm{C}\right)$ and humidity $(50$ $70 \%$ ) with a 12-h light/dark cycle (light on from 07:00 18:00 h). They were allowed to adapt to our laboratory environment for $1 \mathrm{wk}$ before the start of the experiment. Animal care was in compliance with applicable guidelines from the Ryukyu University Policy on Animal Care and Use.

\section{Noise exposure}

The white noise was produced by a noise generator (SF-05, Rion Company Ltd., Tokyo, Japan) and amplified by an amplifier which was connected to a loudspeaker. The sound intensity was measured using a sound level meter and maintained at about $90 \mathrm{~dB}$ (A). One group of 10 mice was exposed to noise $5 \mathrm{~h}$ (from 22:00 to 3:00 h) each day at the height of the diurnal activity cycle for 3 consecutive days, and another group of 10 mice were exposed to noise for $4 \mathrm{wk}(28 \mathrm{~d}$ ) with the same exposure protocol. Two control groups, each one with 10 mice, for both the 3-d and 4-wk noise exposure groups, were kept in a quiet room and only exposed to daily activity at 40-50 dB (A) of sound intensity.

The body weights of mice in each group were measured before the start of the experiment and after the end of the experiment.

\section{Determination of hormone levels}

On the 4th or the 29th day, blood was obtained from both exposed and control mice and serum was prepared and stored at $-80^{\circ} \mathrm{C}$ for later analysis. The serum corticosteroid was measured using the fluorescence polarization immunoassay (FPIA $)^{7}$. Plasma catecholamines, such as adrenaline and dopamine, were measured using a three-column system of high performance liquid chromatography (HPLC) $)^{8}$.

\section{Splenic lymphocyte proliferation assay}

Spleens were aseptically resected and a single-cell suspension was obtained by teasing the tissue through 50-mesh stainless steel wire screens into iced cold RPMI 1640. The cell suspension was treated with $0.1 \mathrm{~mol} / l$ Tris $\cdot \mathrm{HCl}$, pH 7.2, containing $8 \mathrm{~g} / l$ Tris ammonium chloride to lyse red blood cells. Spleen cells $\left(5 \times 10^{5}\right.$ cells per well) in complete RPMI 1640 containing $10 \%$ fetal bovine serum, $100 \mathrm{U} / \mathrm{m} l$ penicillin and $100 \mathrm{U} / \mathrm{m} l$ streptomycin were dispensed into 96-well flat-bottomed microtiter plates and cultured in triplicate for $30 \mathrm{~h}$ at $37^{\circ} \mathrm{C}$ in a humidified $5 \% \mathrm{CO}_{2}$ incubator in the presence of 5 $\mu \mathrm{g} / \mathrm{m} l$ concanavalin A (ConA) (Sigma, USA). Cells cultured without ConA served as a negative control. Lymphocyte blastogenic response was determined by the method of Hansen et al. ${ }^{9}$, which is a modification of the method of Mossman ${ }^{10)}$. Briefly, $25 \mu l$ of $1 \mathrm{mg} / \mathrm{ml} 3-(4$, 5-dimethyl-2-thiazoly)2, 5-diphenyl-2h-tetrazolium bromide (MTT) was added to each lymphocyte culture. After $1 \mathrm{~h}$ incubation, $100 \mu \mathrm{l}$ of extraction buffer was added. After overnight incubation, the absorbance was measured at $570 \mathrm{~nm}$. The mitogen response was calculated as the mitogen stimulation index.

\section{Lymphocyte subset analysis}

Single cell suspensions from thymus and spleen were prepared and lymphocyte subpopulations were identified by phenotypic analysis of surface markers. Briefly, $1 \times$ $10^{6}$ cells in PBS were stained with $10 \mu \mathrm{l}$ of a mixture of labeled monoclonal antibodies (CD4 or CD8) at $4{ }^{\circ} \mathrm{C}$ for $20 \mathrm{~min}$ in the dark. The cells were washed once with PBS and then filtrated through nylon mesh. The stained cells were analyzed for their fluorescence intensity by flow cytometry.

\section{Serum antibody determination}

Total serum IgM and $\mathrm{IgG}$ were determined using mouse

Table 1. Blood hormone (corticosteroid, adrenaline and dopamine) levels in control mice and noise-exposed mice

\begin{tabular}{lccc}
\hline & Corticosteroid $(\mu \mathrm{g} / \mathrm{d} l)$ & Adrenaline $(\mathrm{pg} / \mathrm{m} l)$ & Dopamine $(\mathrm{pg} / \mathrm{m} l)$ \\
\hline Control & $1.60 \pm 0.35$ & $723.8 \pm 100.3$ & $353.5 \pm 93.7$ \\
Noise $(3 \mathrm{~d})$ & $5.58 \pm 1.41^{*}$ & $1756.9 \pm 221.3^{*}$ & $397.1 \pm 127.1$ \\
Control & $2.08 \pm 0.72$ & $792.8 \pm 69.6$ & $415.9 \pm 97.8$ \\
Noise $(4 \mathrm{wk})$ & $4.25 \pm 1.03^{*}$ & $954.9 \pm 189.8^{\#}$ & $479.0 \pm 94.2$ \\
\hline
\end{tabular}

Mice were exposed to noise for $3 \mathrm{~d}$ or $4 \mathrm{wk}$. Values are expressed as means \pm SD. Each group had 10 mice. *Significantly different from control value at $p<0.01$; "Significantly different from control value at $p<0.05$. 
IgM ELISA quantitation Kit (Bethyl Laboratories, Inc, TX, USA) and mouse IgG ELISA quantitation Kit (Bethyl Laboratories, Inc, TX, USA), respectively, according to the manufacturer's instructions.

\section{Oxidative stress analysis}

Urine was collected and centrifuged. 8-hydroxy-2'deoxyguanosine $(8-\mathrm{OHdG})$ in urine was determined using the ELISA method with a New 8-OHdG Check Kit (Japan Institute for the Control of Aging, Shizuoka, Japan) according to the manufacturer's instructions and adjusted against urinary creatinine. The limit of detection in urinary $8-\mathrm{OHdG}$ is $0.5-200 \mathrm{ng} / \mathrm{ml}$.

\section{Statistical analysis}

Statistical analysis of data was performed by using Student's t-test. A value of $p<0.05$ was considered significant.

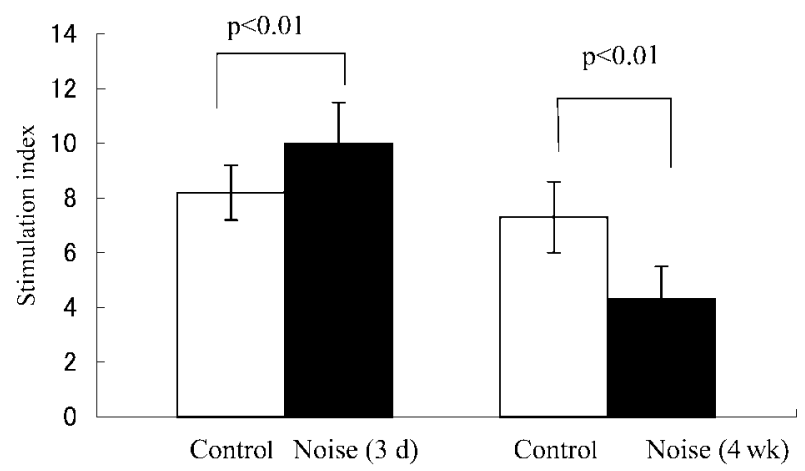

Fig. 1. ConA-induced splenic lymphocyte proliferation (stimulation index) in control mice and noise-exposed ( $3 \mathrm{~d}$ or $4 \mathrm{wk}$ of exposure) mice. Values are expressed as means $\pm \mathrm{SD}$. Each group has 10 mice.

\section{Results}

Blood hormone levels

As shown in Table 1, corticosteroid and adrenaline levels in control mice were $1.6 \mu \mathrm{g} / \mathrm{d} l$ and $723.8 \mathrm{pg} / \mathrm{m} l$, respectively. Three days of exposure to noise stress resulted in a 2.5 -fold increase of corticosteroid $(5.58 \mu \mathrm{g} /$ $\mathrm{d} l, p<0.01)$ and a 1.5-fold increase of adrenaline (1756.9 $\mathrm{pg} / \mathrm{ml}, p<0.01)$. Dopamine concentrations between control and noise-exposed mice were not significantly different.

After $4 \mathrm{wk}$ of exposure to noise, corticosteroid was increased from 2.08 to $4.25 \mu \mathrm{g} / \mathrm{d} l(p<0.01)$ and adrenaline was increased from 792.8 to $954.9 \mathrm{pg} / \mathrm{ml}(p<0.05)$ as compared to the control, but dopamine was not significantly changed.

The weight gains in the same cage of mice before and after the experiment were not significantly different.

\section{Lymphoproliferative responses}

Figure 1 shows the splenic lymphoproliferative responses expressed as a stimulation index. After mice were exposed to noise stress for $3 \mathrm{~d}$, splenic lymphoproliferation was significantly increased as compared to that in control mice (8.17 vs $9.99, p<0.01$ ). However, after $4 \mathrm{wk}$ of exposure, splenic lymphoproliferation was significantly decreased in exposed mice as compared to control mice (4.33 vs 7.27 , $p<0.01)$.

\section{Lymphocyte subsets}

As shown in Fig. 2, when mice were exposed to $3 \mathrm{~d}$ of noise, the percentage of $\mathrm{CD}^{+}$or $\mathrm{CD}^{+}$cells in the spleen was not significantly different from that in control mice. However, $\mathrm{CD}^{+}{ }^{+}$cells in the spleen were significantly reduced after 4 wk of exposure, although $\mathrm{CD}^{+}$cells were not significantly changed between exposed and control

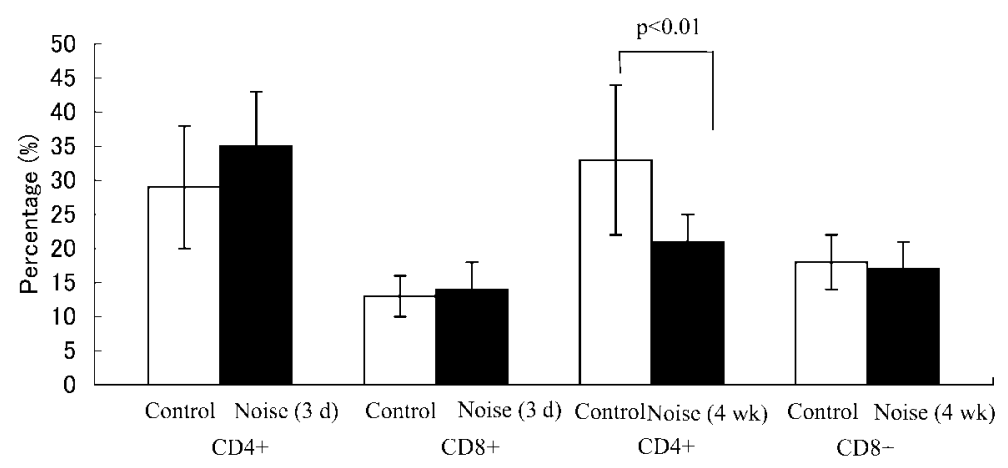

Fig. 2. The percentages of $\mathrm{CD} 4^{+}$and $\mathrm{CD} 8^{+}$cells in the spleen in control mice and noise-exposed ( $3 \mathrm{~d}$ or $4 \mathrm{wk}$ of exposure) mice. Values are expressed as means $\pm \mathrm{SD}$. Each group has 10 mice. 


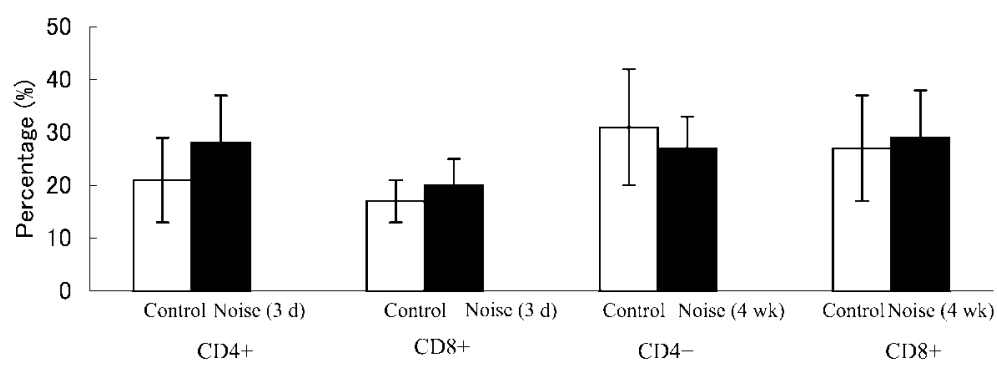

Fig. 3. The percentages of $\mathrm{CD} 4^{+}$and $\mathrm{CD}^{+}$cells in the thymus of control mice and noise-exposed ( $3 \mathrm{~d}$ or $4 \mathrm{wk}$ of exposure) mice. Values are expressed as means $\pm \mathrm{SD}$. Each group has 10 mice.

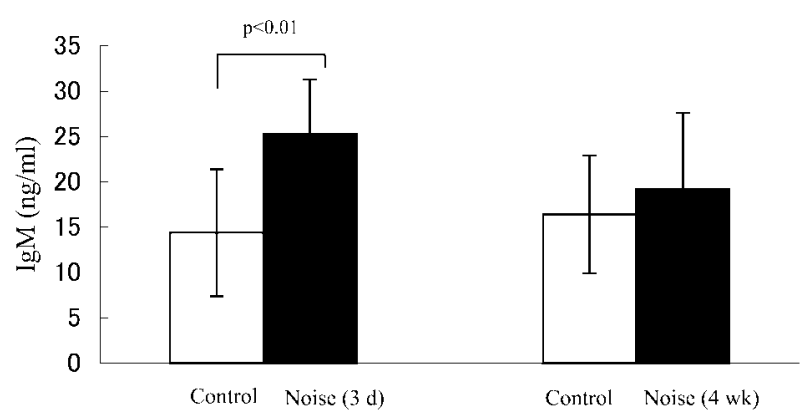

Fig. 4. Total serum IgM levels in control mice and noiseexposed ( $3 \mathrm{~d}$ or $4 \mathrm{wk}$ of exposure) mice. Values are expressed as means $\pm \mathrm{SD}$. Each group has 10 mice.

mice.

Figure 3 shows that the percentage of $\mathrm{CD}^{+}$or $\mathrm{CD} 8^{+}$ cells in the thymus was not significantly different between exposed and control mice either after $3 \mathrm{~d}$ of exposure or after $4 \mathrm{wk}$ of exposure.

\section{Serum antibodies}

Figure 4 shows the changes of serum IgM concentrations. A 3-day exposure to noise resulted in a significant increase of serum IgM as compared to control mice $(25.4 \mathrm{ng} / \mathrm{m} l$ vs $14.4 \mathrm{ng} / \mathrm{m} l, p<0.01)$, whereas they were not significantly different between exposed and control mice after 4 wk exposure to noise $(14.4 \mathrm{ng} / \mathrm{m} l \mathrm{vs}$ $19.2 \mathrm{ng} / \mathrm{m} l, p>0.05)$.

As shown in Fig. 5, four weeks of exposure to noise caused a significant decrease of serum $\mathrm{IgG}$ in exposed mice as compared to control mice $(22.1 \mathrm{ng} / \mathrm{m} l$ vs 57.3 $\mathrm{ng} / \mathrm{ml}, p<0.01)$, although it was not significantly changed after $3 \mathrm{~d}$ of exposure $(48.3 \mathrm{ng} / \mathrm{m} l \mathrm{vs} 42.3 \mathrm{ng} / \mathrm{m} l, p>0.05)$.

\section{Oxidative stress}

Figure 6 shows urinary 8-OHdG concentrations in exposed and control mice. Although urinary $8-\mathrm{OHdG}$ was not significantly different between exposed and control mice $(20.1 \mathrm{ng} / \mathrm{m} l \mathrm{vs} 18.3 \mathrm{ng} / \mathrm{m} l, p<0.05)$ after 3 days of noise exposure, it was significantly increased in

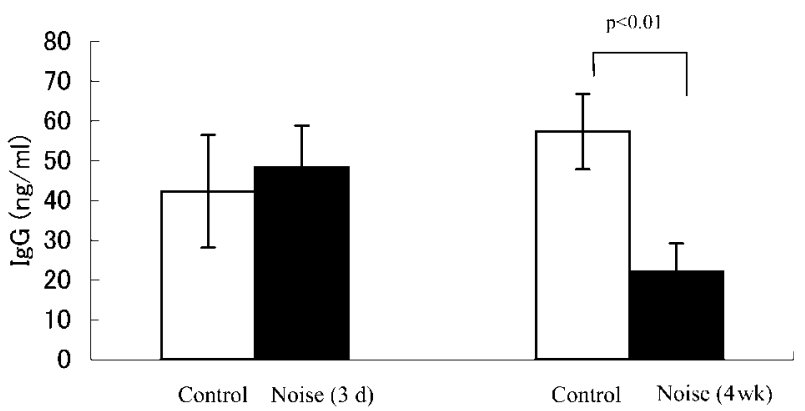

Fig. 5. Total serum IgG levels in control mice and noiseexposed ( $3 \mathrm{~d}$ or $4 \mathrm{wk}$ of exposure) mice. Values are expressed as means $\pm \mathrm{SD}$. Each group has 10 mice.

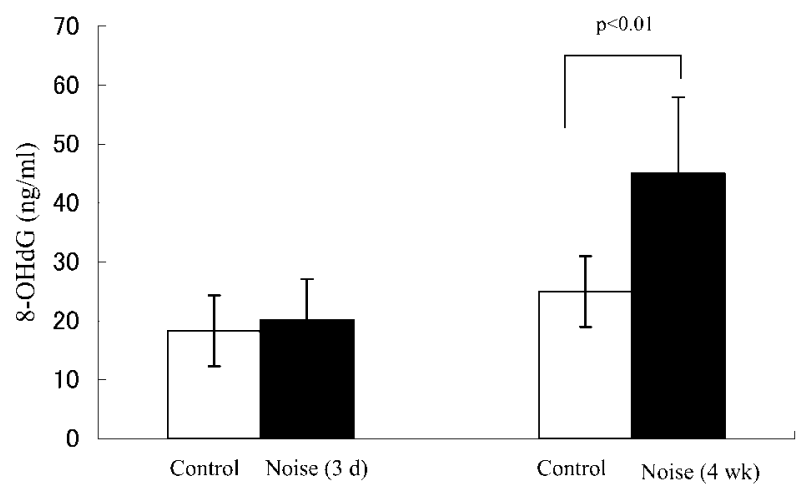

Fig. 6. Urinary 8-OHdG concentrations in control mice and noise-exposed ( $3 \mathrm{~d}$ or $4 \mathrm{wk}$ of exposure) mice. Values are expressed as means $\pm \mathrm{SD}$. Each group has 10 mice.

exposed mice over that in control mice $(44.2 \mathrm{ng} / \mathrm{m} l \mathrm{vs}$ $24.9 \mathrm{ng} / \mathrm{m} l, p<0.01)$ after $4 \mathrm{wk}$ of noise exposure.

\section{Discussion}

Due to the increasing trend of noise exposure in general living environments both in industrialized nations and in developing world regions, the pathogenesis resulting from noise stress needs to be well clarified. The present study 
was undertaken to determine the effect on the immune function and oxidative status following a short period or a long period of noise stress. Our results show a 3-d exposure to noise resulted in the enhancement of immune responses expressed as the elevated ConA-induced splenic lymphoproliferative responses and serum IgM levels, whereas a 4-wk exposure to noise stress resulted in the suppression of immune functions manifested as reduced levels of lymphoproliferative responses and $\mathrm{CD}^{+}$ cells in the spleen, and decreased serum IgG concentrations.

Exposure to aversive events or stressors affects various aspects of the immune function. It has been indicated that the innate non-specific immune response, as well as the specific immune response, may be altered by stress ${ }^{11,12}$. However, the stress-induced effects may be variable depending on the type and characteristics of the stressor, the specific immune parameter under investigation, and the time passed between exposure to the stressor and monitoring of the immune function. Noise exposure has long been used as a stressor to investigate its effect on biological and biochemical responses. In a rat model exposed to $80 \mathrm{~dB}$ of rock music for $24 \mathrm{~h}$, macrophage secretion of IL-1 and neutrophil release of $\mathrm{O}_{2}^{-}$anion were reduced $^{13)}$. Another animal model in C57/BL6 mice showed that exposure to unpredictable $100 \mathrm{~dB}$ noise stress for $1 \mathrm{wk}$ resulted in the reduction of both splenic Thy ${ }^{+}$ lymphocytes (indicator for T-lymphocytes) and Lyt-1.2+ lymphocytes (functionally similar to human T-helper cells) ${ }^{14)}$. These 2 experiments showed a suppressive effect on cell-mediated immune function caused by acute noise stress. However, our data showed an enhancement effect on both cellular and humoral immune functions caused by $3 \mathrm{~d}$ of noise stress.

Our data also showed that $4 \mathrm{wk}$ of exposure to noise stress caused suppression not only of cellular immune functions, but also of humoral function. These results are in agreement with the report by Aguas, et al. ${ }^{15}$. In their experiment, BALB/c mice exposed to low-frequency noise ( $\geq 90 \mathrm{~dB}, \leq 500 \mathrm{~Hz}$ ) for 8 months showed decreases in $\mathrm{CD}^{+}$and $\mathrm{CD}^{+} \mathrm{T}$ splenic lymphocytes and in $\operatorname{IgM}^{+} \mathrm{B}$ lymphocytes. Furthermore, they also reported that a long term (2,184 cumulative hours) exposure to low-frequency noise could suppress the normal immune response to bacterial infection in Wistar rats ${ }^{16}$. On the other hand, the report by Lange et al. showed that 4 wk of exposure to $100 \mathrm{~dB}$ noise in C57/BL6 mice did not change splenic $\mathrm{Thy}^{+}$lymphocytes and Lyt-1.2+ lymphocytes ${ }^{14)}$. Moreover, Monjan and Collector demonstrated in their study that 4 or 5 wk of exposure to $120 \mathrm{~dB}$ noise enhanced T-cell activity in mice ${ }^{17)}$. The limited contradictory results of the above studies do not allow a consistent interpretation of the effect of noise stress on the immune function. The discrepancy among our results and the results previously reported by other researchers might be due to the difference of animal species, sound intensity, exposure duration or animal handling applied in the experiment. In addition, it might be that noise stress has variable effects on the different immune parameters monitored in the studies. The study performed on Wistar rats exposed to intermittent noise $(85 \mathrm{~dB})$ for different period $(24 \mathrm{~h}, 7 \mathrm{~d}$ and $21 \mathrm{~d})$ indicated that various parameters of the immune function are affected differentially over time in a period of chronic noise stress, possibly due to sequential activation of different physiological mechanisms ${ }^{18)}$.

Noise stress has been found to induce neuroendocrine effects in humans and animals ${ }^{19,20)}$. It has been revealed that corticotropin-releasing hormone is released during stress and stimulates the release of adrenocorticotrophic hormone ${ }^{21)}$, which in turn releases corticosterone from the adrenal cortex. Elevation of the corticosterone level accelerates the generation of free radicals ${ }^{22}$ and suppresses the immune function ${ }^{23)}$. However, in the present study, although corticosteroid and adrenaline levels were significantly increased after $3 \mathrm{~d}$ as well as after $4 \mathrm{wk}$ of noise stress, the noise-induced modulation of the immune response was not consistent between these two different exposure periods. This might imply that besides hormones, other factors or mechanisms may also account for the effect of noise stress on the immune response.

Oxygen free radicals can cause a variety of damage to DNA, including DNA single and double strand breaks, base modifications and abasic sites ${ }^{24-26)}$, and they are thought to be involved in the mechanisms of aging and in carcinogenesis and other disorders ${ }^{27,28)}$. Recent evidence has shown that stress can alter hormonal levels, lymphocyte subsets and the production of reactive oxygen species $^{29)}$. In a rat model reported by Srikumar et al., noise stress significantly increased the lipid peroxidation with concomitant depletion of antioxidants, but significantly suppressed the cell-mediated immune respons $\mathrm{e}^{30)}$. Free radical imbalance in the hippocampus and medial prefrontal cortex has been documented to be related with spatial memory error caused by chronic noise stress in the rat ${ }^{4)}$. To investigate oxidative status caused by noise stress, $8-\mathrm{OHdG}$ was determined in the present study. 8-OHdG, a DNA base-modified product ${ }^{31)}$ generated by reactive oxygen species, is mutation prone ${ }^{32)}$ and has been shown to be a good marker of oxidative damage $^{32)}$. Therefore, the formation of $8-\mathrm{OHdG}$ in DNA and its urinary excretion have been frequently measured to assess oxidative stress in humans. Our results for urinary $8-\mathrm{OHdG}$ show that oxidative stress was significantly increased following $4 \mathrm{wk}$ of noise exposure. The increased oxidative stress might partially account for the suppression of the cellular and humoral immune functions caused by noise exposure in our study.

In conclusion, the results of the present study indicate 
that short-term exposure to noise stress may enhance the immune function, whereas long-term exposure may result in suppression of the cellular and humoral immune responses. The mechanisms underlying noise-induced reduction of the immune function may be related not only to neuroendocrine change, but also to the imbalance of oxidative stress.

\section{References}

1) Passchier-Vermeer W and Passchier WF: Noise exposure and public health. Environ Health Perspect 108, 123-131 (2000)

2) Branco Castelo NAA: The clinical stages of vibroacoustic disease. Aviat Space Environ Med 70, A32-A39 (1999)

3) Wyscoki $\mathrm{AB}$. The effect of intermittent noise exposure on excisional wound healing in albino rats. In: 1987 International Nursing Research Conference, American Nurses Association Abstract. 1987: 459.

4) Manikandan S, Padma MK, Srikumar R, Jeya PN, Muthuvel A and Sheela DR: Effects of chronic noise stress on spatial memory of rats in relation to neuronal dendritic alteration and free radical-imbalance in hippocampus and medial prefrontal cortex. Neurosci Lett 399, 17-22 (2006)

5) Campen LEV, Murphy WJ, Franks JR, Mathias PI and Toraason MA: Oxidative DNA damage is associated with intense noise exposure in the rat. Hearing Research 164, 29-38 (2002)

6) Rabinowitz PM, Wise JP, Mobo BH, Antonucci PG, Powell C and Slade M: Antioxidant status and hearing function in noise-exposed workers. Hearing Research 173, 164-171 (2002)

7) Jolley ME, Stroups SD, Wang CHJ, Panas HN, Keegan CL, Schmidt RL and Schwenzer KS: Fluorescence polarization immunoassay. I. Monitoring aminoglycosid antibiotics in serum and plasma. Clin Chem 27, 1190-1197 (1981)

8) Yoshimura M, Komori T, Nakanishi $T$ and Takahashi $\mathrm{H}$ : Estimation of sulphoconjugated catecholamine concentrations in plasma by high-performance liquid chromatograph. Ann Chin Biochem 30, 135-141 (1993)

9) Hansen MB, Nielsen SE and Berg K: Re-examination and further development of a precise and rapid dye method for measuring cell growth and kill. J Immunol Methods 119, 203-210 (1989)

10) Mossman T: Rapid colorimetric assay for cellular growth and survival: application to proliferation and cytotoxic assay. J Immunol Methods 65, 55-63 (1983)

11) Dantzer R and Kelley KW: Stress and immunity: An integrated view of relationships between the brain and the immune system. Life Sci 44, 1995-2008 (1989)

12) Kusnecov AW and Rabin BS: Stressor-induced alterations of immune function: mechanisms and issues. Int Arch Allergy Immunol 105, 107-121 (1994)

13) McCarthy DO, Ouimet ME and Daun JM: The effects of noise stress on leukocyte function in rats. Research in Nursing \& Health 15, 131-137 (1992)
14) Lange KW, Kugler J and Kalveram KT: Influence of short- and long-term noise stress on splenic lymphocytes in the mouse. Med Sci Res 17, 385-386 (1989)

15) Aguas AP, Esaguy N, Grande N, Castro AP and Castelo Branco NAA: Effect of low frequency noise exposure on BALB/c mice splenic lymphocytes. Aviat Space Environ Med 70, A128-A131 (1999)

16) Oliveira MJ, De Sousa PA, Aguas AP, Grande NR, Monteiro E, Serrano I and Castelo Branco NA: Effect of low frequency noise upon the reaction of pleural milky spots to mycobacterial infection. Aviat Space Environ Med 70, A137-A140 (1999)

17) Monjan AA and Collector MI: Stress-induced modulation of the immune response. Science 196, 307308 (1977)

18) Raaij MTMV, Oortgiesen M, Timmerman HH, Dobbe CJG and Loveren HV: Time-dependent differential changes of immune function in rats exposed to chronic intermittent noise. Physiol Behav 60, 1527-1533 (1996)

19) De Boer SF, Van DG and Slangen JL: Plasma catecholamine and corticosterone responses to predictable and unpredictable noise stress in rats. Physiol Behav 45, 789-795 (1989)

20) Scheurink A, De Boer SF, Korte M and Korte BG. Catecholamine and corticosterone responses to various stressors. In: Proceedings of the Satellite Symposium "The neurobiology of stress". The Netherlands, 1995: 45.

21) Owens MJ and Nemeroff CB: Physiology and pharmacology of corticotrophin-releasing factor. Pharmacol Rev 91, 425-473 (1991)

22) McIntosh LJ, Sapolsky RM: Glucocorticoid increase the accumulation of reactive oxygen species and enhance adriamycin-induced toxicity in neuronal culture. Exp Neurol 141, 201-206 (1996)

23) Cunnik JE, Lysle DT, Kucinski BJ and Rabin BS: Evidence that shock-induced immune suppression is mediated by adrenal hormones and peripheraladrenergic receptors. Pharmacol Biochem Behav 36, 645-651 (1990)

24) Cadet J, Berger M, Douki T and Ravanat JL: Oxidative damage to DNA: formation, measurement and biological significance. Rev Physiol Biohem Pharmacol 131, 1-87 (1997)

25) Epe B: DNA damage profiles induced by oxidizing agents. Rev Physiol Biohem Pharmacol 127, 223-249 (1997)

26) Dizdaroglu M: Chemical determination of free-radical induced damage to DNA. Free Radic Biol Med 10, 225-242 (1991)

27) Finkel $\mathrm{T}$ and Holbrook NJ: Oxidants, oxidative stress and the biology of aging. Nature 408, 239-247 (2000)

28) Beckman KB and Ames BN: Oxidative decay of DNA. J Biol Chem 272, 19633-19636 (1997)

29) Atanackovic D, Brunner-Weinzierl MC, Kroger H, Serke S and Deter HC: Acute psychological stress simultaneously alters hormone levels, recruitment of lymphocytes subsets, and production of reactive 
oxygen species. Immunol Invest 31, 73-91 (2002)

30) Srikumar R, Parthasarathy NJ, Manikandan S, Narayanan GS and Sheeladevi R: Effect of triphala on oxidative stress and on cell-mediated immune response against noise stress in rats. Mol Cell Biochem 283, 67-74 (2006)

31) Kasai H, Crain PF, Kuchino Y, Nishimura S, Ootsuyama A and Tanooka H: Formation of 8- hydroxyguanine moiety in cellular DNA by agents producing oxygen radicals and evidence for its repair. Carcinogenesis 7, 1849-1851 (1986)

32) Pilger A and Rudiger HW: 8-Hydroxy-2'deoxyguanosine as a marker of oxidative DNA damage related to occupational and environmental exposure. Int Arch Occup Environ Health (Epub ahead of print, 2006) 